\title{
UPAYA PENINGKATAN PENDAPATAN EKONOMI MASYARAKAT BAKALAN KRAJAN SECARA BERKELANJUTAN MELALUI EKSTENSIFIKASI PETERNAKAN JANGKRIK DAN DOMBA
}

\author{
Retno Susilowati ${ }^{1}$, Mujahidin Ahmad ${ }^{1}$, Kholifah Holil ${ }^{1}$, Prima Kurniawaty ${ }^{2}$ \\ ${ }^{1}$ Jurusan Biologi, UIN Maulana Malik Ibrahim Malang \\ ${ }^{2}$ Jurusan Teknik Arsitektur, UIN Maulana Malik Ibrahim Malang \\ susilowatiretno_pd@yahoo.com,mujahidin@uin-malang.ac.id,primakurniawaty@arch.uin-malang.ac.id
}

\section{Info Artikel \\ Riwayat Artikel: \\ Diterima: September 2017 \\ Direvisi: Agustus 2019 \\ Diterbitkan: September 2019}

\section{Keywords:}

Extensification

Breeder

Cricket

Sheep

Productivity

\begin{abstract}
The potential of human resources and natural resources in the village of krajan will not be maximally exploited. Potential Human Resources include the ability of the community to work together in livestock business and Natural Resources including the availability of abundant forage forage in the rainy season. The use of fodder forage for sheep and cattle feed traditionally has not provided significant income for the community besides traditional maintenance will take a long time. Extensification of livestock business with income that can be generated in the short term is very urgent to do immediately. Cricket is a potential livestock business to be developed considering the relatively short production cycle of only 1 month while the fattening program or sheep fattening is also relatively short, which takes about 3 months to harvest. The construction of cricket cages and the expansion of sheep cages of joint business groups owned by the residents of krajan are expected to be able to increase community income both in the short term (1-3 months) or long term (annual). Community service using the active partition method has been successfully carried out with the following work programs; 1) cricket cage production capacity of $250 \mathrm{~kg} / \mathrm{month}, 2$ ) sheep fattening cages from a capacity of 30 heads to 80 heads, 3 ) training in making silage and ammoniation and complete feed for sheep, 4) improving the genetic quality of sheep by producing cempe and super sheep enlargement. The results of the first period cricket production trials were $31 \mathrm{~kg}$ (from 2 boxes) or $31-32$ of the target $(50 \mathrm{~kg} / \mathrm{box})$, the second trial produced $60 \mathrm{~kg}$ (of 2 boxes) or $60 \%$ of the target and the third trial produced $124 \mathrm{~kg}$ (from 4 boxes) or $62 \%$ of the target. The benefit gained in each period is Rp. 400,000/box per harvest. While the expansion of the sheep pen has an impact on investor interest in the investment of fattening rams so that the males for fattening, which originally came from only 2 to 30 , have increased 15 -fold to date. The increase in sheep population will potentially increase the income of Rp. 500,000/breeder/month or Rp. 100,000/head/month. The low yield of crickets from the target is caused by several factors, including seasonal changes and unstable feed sources and production management by farmers who lack discipline in feeding. Whereas in sheep, breeding and fattening systems face obstacles including the provision of alternative feed which cannot be implemented optimally due to the absence of copper or forage counters and fleece cutting machines. If the two tools are fulfilled the optimization of income from the sheep sector will be significantly increased.
\end{abstract}




\section{Korespondensi:}

Retno Susilowati,

UIN Maulana Malik Ibrahim Malang,

Jl. Gajayana No. 50 Malang, Jawa Timur, Indonesia 65144

susilowatiretno_pd@yahoo.com

\section{PENDAhuluan}

Menurut Bappenas (2014) angka kemiskinan di Indonesia cukup tinggi yaitu sekitar 29 Juta orang pada tahun 2012. Walaupun negara ini mencatat kemajuan yang signifikan dalam pengentasan kemiskinan selama dekade lalu. Namun terjadi perlambatan laju pengentasan kemiskinan. Hal ini ditambah serta pesatnya peningkatan kekayaan, kesenjangan antara kelompok kaya dan kelompok miskin yang semakin melebar (The World Bank, 2014). Sebab terbesar terjadinya distribusi kesenjangan dan kemiskinan menurut head count index adalah disebabkan karena pengangguran, yaitu dengan kisaran 6,18\% di daerah kota sedangkan di daerah desa 3,78\% (Bappenas, 2014).

Kemiskinan dan kesenjangan ini merupakan problem ekonomi dan sosial yang dapat mendorong seseorang melakukan tindakan-tindakan yang tak dibenarkan agama. Karenanya, tidak bisa disalahkan jika ada ungkapan bahwa kefakiran atau kemiskinan mendekatkan kepada kekufuran. Diriwayatkan bahwa Rasulullah Shallallahu 'Alaihi Wasallam bersabda,

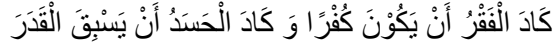

"Hampir-hampir saja kefakiran akan menjadi kekufuran dan hampir saja hasad mendahului takdir." Karenanya juga Al-Musthafa Shallallahu 'Alaihi Wasallam berlindung dari kefakiran." Seperti doa Nabi Shallallahu 'Alaihi Wasallam,

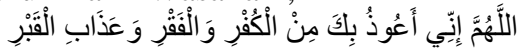

"Ya Allah, Sesungguhnya aku berlindung kepadaMu dari kefakiran dan kekufuran serta adzab kubur." (HR. Abu Dawud, Al-Nasai, dan Ahmad)

Kemakmuran dan kesejahteraan masyarakat dapat dengan mudah diwujudkan diantaranya adalah dengan upaya peningkatan kualitas sumber daya manusia melalui pendidikan (Ndakularak, et al, 2012; Algifari. 2011). Hal ini bukan hanya kewajiban bagi pemerintah, namun kewajiban setiap elemen bangsa Indonesia. Pemberdayaan masyarakat berbasis sains dan teknologi adalah program yang sangat berpotensi membantu program pemerintah dalam peningkatan kualitas ekonomi dan pendidikan masyarakat. Hal ini sangat selaras dengan tujuan pemerintah dan undang uandang dasar serta sila keadilan sosial bagi seluruh Indonesia.

Perguruan tinggi sebagai elemen kekeuatan bangsa memiliki potensi yang strategis sebagaimana tugas pokok dan fungsinya yaitu sebagai agen of change yaitu perannya sebagai Pendidik dan pengajar, peneliti serta menjawab berbagai problem yang dimiliki oleh masyarakat. Dengan kapasitas yang dimiliki PT diharapkan mampu menjawab berbagai problem multidimensional di sekitarnya, diantaranya pengangguran, pendidikan, dan kemandirian ekonomi.

Kelurahan Bakalan Krajan Kecamatan Sukun Kota Malang adalah suatu wilayah di Kota Malang yang memiliki potensi besar untuk dijadikan sebagai salah satu wisata edukasi dan lingkungan, mengingat posisinya yang strategis dan berbagai potensi diantaranya; ketersediaan lahan yang relatif masih luas untuk usaha pertanian, peternakan dan perikanan. Demikian juga ketersediaan air bersih sepanjang waktu dan keberadaan kelompok-kelompok usaha bersama milik warga menjadi kekuatan dari wilayah ini. Namun semua potensi itu belum terkelola dengan maksimal karena keterbatas SDM dan tenaga ahli yang mampu melakukan transformasi ilmu pengetahuan. Karenanya diperlukan program pemberdayaan masyarakat yang menjadikan masyarakat bakalan krajan sebagai subjek untuk meningkatkan kualitas SDM dalam mengelola potensi yang ada berbasis minat masyarakat dan daya dukung lingkungan.

Peternakan dan pertanian adalah dua hal yang diminati namun belum tergarap secara maksimal oleh masyarakat Bakalan Krajan. Diantara kelompok usaha yang belum tergarap maksimal adalah kelompok ternak jangkrik dan domba. Kedua komoditi tersebut sangat menjanjikan. Ternak jangkrik misalnya, dengan siklus produksi yang hanya 1 bulan menjadikannya dapat dijadikan peluang usaha dalam rangka peningkatan kualitas ekonomi jangka pendek (Burm, 2000; Delfianizar dan Kasmeri, 2011). Sedangkan ternak domba juga memiliki potensi yang besar untuk dikembangkan mengingat kebutuhan daging domba dari waktu ke waktu yang terus meningkat (Soedjana, 2011; Tirtamulya \& Karawang, 2007). Dalam ternak domba dikenal 
dua jenis sistem produksi yaitu breeding atau pembibitan untuk menghasilkan cempe berkualitas dan fattening atau penggemukan. Program fattening diperlukan sekitar 3 bulan dalam satu siklus produksi, sedangkan program breeding (pembibitan) akan menghabiskan waktu sekitar 8 bulan s/d1 tahun per siklus produksi (Nuraini, 2014). Pelatihan dan pemenuhan sarana prasarana budidaya jangkrik dan domba terutama kandang merupakan kebutuhan utama terlaksananya program ini, demikian juga pelatihan terkait manajemen pemeliharaan dan peracikan pakan akan sangat menentukan keberhasilan suatu usaha peternakan.

\section{METODE PENELITIAN}

Objek pengabdian adalah kelompok usaha ternak yang ada di RT 1 RW 1 Bakalan Krajan Kota Malang, yaitu kelompok ternak jangkrik "Sumber Rejeki" yang beranggotakan 5 orang dan Kelompok Usaha Bersama (KUBE) Domba "Husnul Khotimah" yang beranggotakan 8 orang dengan jumlah populasi domba yang dipelihara sebanyak 30 ekor.

Metode pengabdian masyarakat yang digunakan adalah survey, analisis SWOT, dan pelaksanaan dengan melibatkan masyarakat secara langsung (partisipatif) yang meliputi 3 tahapan utama yaitu; persiapan, pelaksanaan dan evaluasi. Pada tahap survey dilakukan studi pustaka dan wawancara kepada masyarakat terkait problem yang dihadapi sekaligus tawran untuk penyelesainnya. Hasil studi pustaka dan wawancara selanjutnya dianalisis dengan analisis SWOT untuk mengetahui potensi kekuatan, kelemahan, peluang dan ancaman yang dihadapi. Berikutnya pada tahap pelaksanaan dilakukan 3 tahapan, (a) persiapan dilakukan dengan melakukan forum grup discussion (FGD) dengan menghadirkan tokoh agama dan masyarakat, untuk dibicarakan berbagai macam peluang dan solusi dari problematika yang dihadapi, pematangan rencana dan pembuatan jadwal kerja (b) pelaksanaan, meliputi kegiatan pelatihan secara teori, pembangunan sarana dan prasarana yang dibutuhkan, dan praktek lapang, selanjutnya (c) dilakukan evaluasi dengan beberapa variabel baik secara kualitatif (perubahan tingkat pengetahuan masyarakat) ataupun kuantitatif dengan variable perubahan pendapatan bulanan peserta program pemberdayaan.

\section{HASIL DAN PEMBAHASAN}

\subsection{Hasil Studi Pustaka dan Survey}

Kelurahan Bakalan Krajan memiliki letak geografis dengan luas wilayah 197.450 Ha dengan ketinggian dan permukaan laut $435 \mathrm{~m} \mathrm{dpl}$, suhu maksimum/minimum 27-30 derajat celcius, curah hujan 240 $\mathrm{mm} /$ tahun dengan topografi bentuk wilayah datar sampai berombak. Kelurahan ini memiliki batas administratif sebagai berikut; Sebelah Utara: Kelurahan Mulyorejo Kecamatan Sukun, Sebelah Timur : Kelurahan Bandungrejosari Kecamatan Sukun, Sebelah Selatan: Desa Sitrejo Kecamatan Wagir dan Sebelah Barat : Desa Sidorahayu Kecamatan Wagir Kabupaten Malang (lihat gambar 1) .

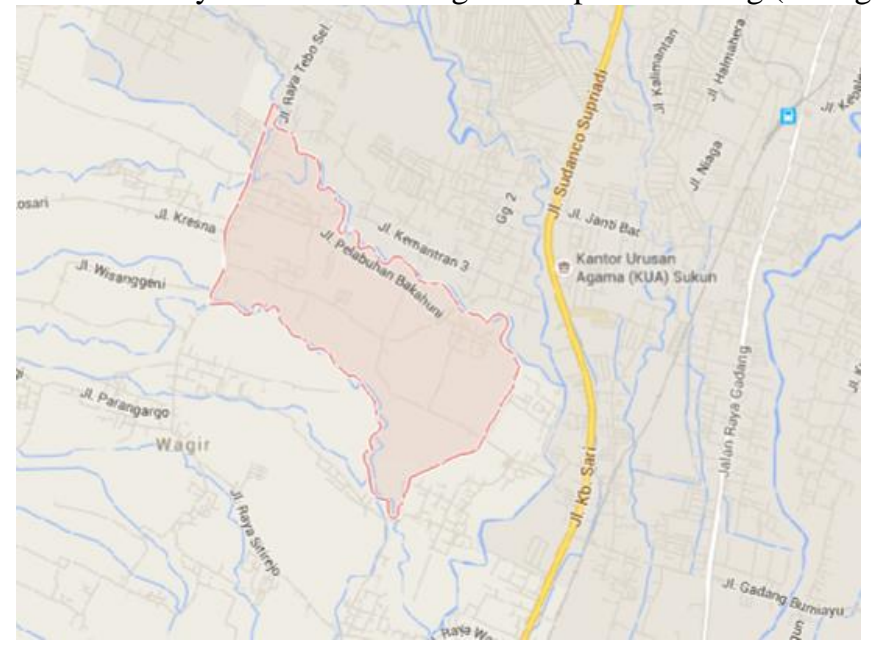

Gambar 1. Wilayah Kelurahan Bakalan Krajan (petak warna merah muda)

Secara demografis, Kondisi Lingkungan bakalan krajan memiliki 46 RT dan 7 RW dengan total jumlah penduduk adalah 7.903 jiwa. Berstatus memeluk agama Islam 7.642 Jiwa, Katholik 253 Jiwa, dan Budha 8 Jiwa. Berdasarkan mata pencahariannya, mayoritas penduduknya (90\%) lebih adalah buruh industri dan bangunan. Sebagaimana disajikan pada gambar 2 berikut: 


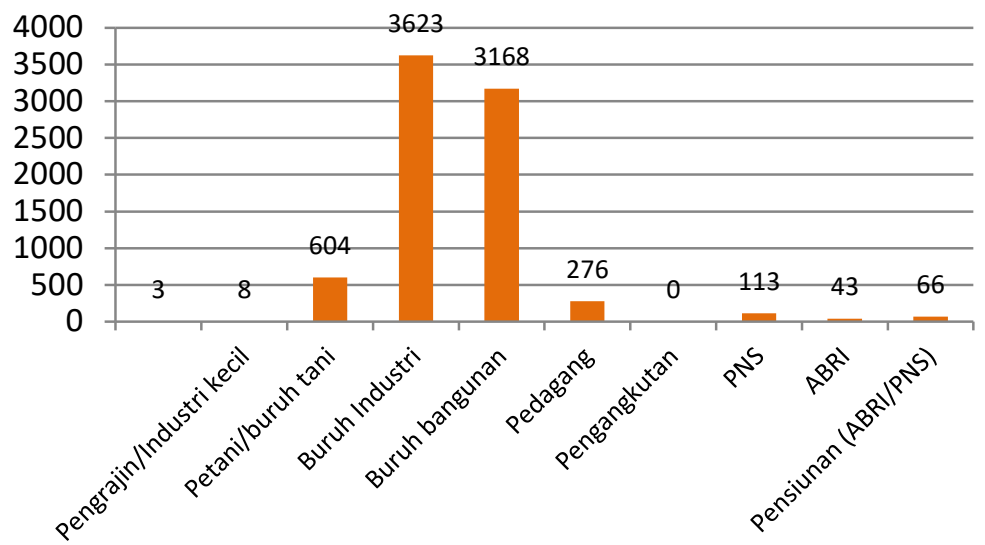

Gambar 2. Demografi penduduk berdasarkan mata pencaharian

Melihat mayoritas penduduknya sebagai buruh dan kuli bangunan, tentu kelurahan Bakalan Krajan dapat dikategorikan memiliki taraf ekonomi menengah kebawah. Problem Pemutusan Hubungan Kerja oleh perusahaan dan faktor lanjut usia akan menjadi penghalang para pekerja tersebut untuk mengangkat ekonomi yang lebih baik di masa yang akad datang. Terobosan baru di tengah masyarakat agar mampu mandiri secara ekonomi dan pekerjaan merupakan tantangan terbesar yang saat ini ada di Kelurahan Bakalan Krajan.

Hasil wawancara dengan Ketua Paguyupan RW di Bakalan (Bapak Santoso) di Kelurahan Bakalan Krajan dapat disimpulkan beberapa fakta berikut;

1. Tingkat ekonomi yang tergolong masih rendah

2. Dengan profesi yang $90 \%$ lebih sebagai buruh pabrik, sawah dan tukang atau kuli bangungan dapat diketahui bahwa pendapatan masyarakat tergolong rendah yaitu pada kisaran Rp. 1 juta.

3. Tingkat Pendidikan yang rendah

4. Dengan kondisi perekonomian yang minim sebagian besar anak-anak banyak yang sudah mulai bekerja ketika lulus dari SD atau SMP untuk meringankan beban ekonomi keluarga. Dengan tingkat pendidikan yang minim dapat dipastikan mereka tidak bisa bersaing dengan angkatan kerja yang pendidikannya lebih tinggi, sehingga menyebabkan profesi yang diambil tidak jauh-jauh dari profesi buruh atau tukang bangunan.

5. Ketergantungan Masyarakat akan pekerjaan diluar daerah

6. Walaupun lahan pertanian di Bakalan Krajan masih luas dan belum termanfaatkan dengan maksimal namun lahan-lahan tersebut sudah dialihfungsikan untuk bangunan dan dikuasai oleh orang-orang diluar daerah sehingga matapencaharian penduduk setempat sangat tergantung dengan pekerjaan diluar daerah. Dengan kondisi yang demikian masa depan pekerjaan semakin sulit diandalkan apalagi dengan bertambahnya usia. Sehingga perlu ada solusi pembukaan peluang pekerjaan alternatif untuk tambahan pendapatan dan persiapan masa tua bagi warga yang fisiknya makin lemah yaitu dengan berwirausaha.

7. Tingkat Relijiusitas yang masih rendah

8. Wilayah Bakalan Krajan RW 1 memiliki 6 masjid yaitu; Masjid Al Mahmudi, Nur Mujahidin, Al Hidayah, Siti Hajar, Nur Nashrulloh dan Al-Amin. Dengan jumlag masjid sedemikian banyak namun seringkali kosong atau sedikit terisa ketika solat berjamaah. Hal ini menunjukkan tingkat keberagamaan masyarakat masih rendah.

9. Sumberdaya alam yang potensial, terutama luas lahan pertanian

\subsection{Hasil Analisis SWOT}

Berikut Hasil analisis SWOT, pada masyarakat dan wilayah bakalan krajan didapat matrix analisis sebagai berikut:

Tabel 1. Hasil analisis SWOT

\begin{tabular}{|l|l|}
\hline \multicolumn{1}{|c|}{ Strengtness (kekuatan) } & \multicolumn{1}{c|}{ Opportunity (peluang) } \\
\hline $\begin{array}{l}\text { Masyarakat yang guyup rukun } \\
\text { - Adanya kelompok KUBE yang sudah } \\
\text { berjalan }\end{array}$ & $\bullet \begin{array}{l}\text { Membentuk KUBE baru dan } \\
\text { mengoptimalkan KUBE yang ada }\end{array}$ \\
- Ketersediaan Hijauan serta air bersih & $\begin{array}{l}\text { Jika masyarakat memiliki ilmu dan } \\
\text { skill pengelolaaan domba dan }\end{array}$ \\
\hline
\end{tabular}


yang melimpah di musim hujan

- Keberadaan pengepul jangkrik yang kebutuhannya belum terpenuhi jangkrik serta dikelola dengan profesioanal dengan teknologi modern diharapkan akan memberikan hasil optimal

- Peluang memenuhikebutuhan jangkrik $150 \mathrm{Kg} /$ hari

\section{Threaten (ancaman)}

- Masyarakat belum terbiasa bekerja secara profesioanal karena selama ini bekerja sebatas sukarela

- Perhitungan dan analisis bisnis belum matang sehingga jika analisis tidak cermat dan kerja tidak professional hasil akan mengecewakan

- Watak masyarakat yang agak sulit menerima informasi dari luar sebelum terbukti

- Persaingan tidak sehat antar peternak dalam KUBE karena sifat dasar egoisme masih kental

- Harga panen jangkrik yang sangat fluktuatif

\subsection{Hasil Pelaksanaan}

\section{i) Persiapan}

Dalam tahap persiapan ini dilakukan Forum Group Discussion (FGD) dengan target pengerucutan hasil analisis SWOT, motivasi wirausaha oleh Tokoh Agama dan Tokoh masyarakat serta penetapan jadwal pelaksanaan, diantara hasil yang didapat dalam FGD adalah diperlukannya 2 kegiatan utama untuk menjawab tantangan yang ada. Yaitu focus pada ekstensifikasi ternak domba dan jangkrik. Adapun kegiatan yang segera dilaksanakan yaitu pelatihan pembuatan pakan domba alternatif, pelatihan pembuatan kandang dan manajemen pemeliharaan domba, pelatihan pembuatan kandang dan budidaya jangkrik. Sehingga dari kesepakatan yang telah dibuat, disusunlah jadwal kegiatan sebagaimana berikut:

Tabel 2. Jadwal Pelaksanaan Program pengabdian dan realisasinya

\begin{tabular}{|llll|}
\hline No & KEGIATAN & $\begin{array}{l}\text { Rencana } \\
\text { PELAKSANAAN }\end{array}$ & Realisasi \\
\hline 1 & $\begin{array}{l}\text { Pembuatan rumah dan kandang } \\
\text { jangkrik }\end{array}$ & 5-17 Oktober 2015 & 5-17 Okteober 2015 \\
\hline 2 & Pelatihan Budidaya Jangkrik & 11 Oktober 2015 & 11 Oktober 2015 \\
\hline 3 & $\begin{array}{l}\text { Pendampingan Pemeliharaan jankrik } \\
\text { I (2 kandang) }\end{array}$ & $\begin{array}{l}\text { 11 Oktober-8 Nopember } \\
\text { 2015 }\end{array}$ & $\begin{array}{l}11 \text { oktober- 14 } \\
\text { nopember 2015 }\end{array}$ \\
\hline 4 & $\begin{array}{l}\text { Perluasan kandang domba dan teknik } \\
\text { budidaya domba: breeding \& } \\
\text { fattening }\end{array}$ & 5-17 Oktober & 5-22 Oktober \\
\hline 5 & $\begin{array}{l}\text { Pelatihan dan paraktek pembuatan } \\
\text { pakan alternative domba }\end{array}$ & 17 dan 18 Oktober & 17 dan 18 Oktober \\
\hline 6 & $\begin{array}{l}\text { Pendampingan breeding dan } \\
\text { fattening domba }\end{array}$ & $\begin{array}{l}\text { 25 November-Januari } \\
\text { 2016 }\end{array}$ & $\begin{array}{l}\text { 25 November-Januari } \\
\text { 2016 }\end{array}$ \\
\hline
\end{tabular}




\section{ii) Pelaksanaan}

\section{Pembuatan rumah dan kandang jangkrik}

Pembuatan rumah jangkrik dengan ukuran $5 \times 8 \mathrm{~m}$ berbahan kayu dan bambu beralas lantai plester semen mampu menampung 5 box kandang jangkrik dengan kapasitas produksi $200-250 \mathrm{Kg} / \mathrm{bulan}$. Pekerjaan ini dilaksanakan oleh masyarakat setempat dengan sistem kerja professional dan dapat diselesaikan dalam waktu 2 minggu.

\section{Pelatihan Budidaya Jangkrik}

Pada pelatihan budidaya jangkrik dilakukan pelatihan dan pembimbingan langsung oleh peternak jangkrik professional dengan materi; penetasan, pemeliharaan, pemanenan dan pemasaran. Jumlah peserta berjumlah 5 orang yang merupakan anggota karangtaruna wilayah bakalan krajan. Metode pelatihan dilakukan dengan ceramah dan praktik langsung di kandang dengan uji coba 2 box/kandang jangkrik terlebih dahulu. Uji coba ini dilakukan untuk tahap pembelajaran bagi persta pelatihan yang belum pernah melakukan budidaya jangkrik sebelumnya

\section{Pendampingan Pemeliharaan jankrik I (2 kandang)}

Pendampingan sangat perlu dilakukan mengingat siklus jangkrik sangat pendek yaitu 3-4 minggu dan membutuhkan kedisiplinan yang sangat tinggi untuk memperoleh hasil yang optimal

\section{Perluasan kandang domba dan teknik budidaya domba: breeding $\&$ fattening}

Perluasan kandang domba bertujuan untuk menambah kapasitas kandang domba agar lebih banyak, disamping itu saat ini hanya dilakukan sistem peternakan breeding atau pembibitan dengan hasil produksi cempe. Dengan adanya tambahan kandang maka dalam waktu yang sama dapat dilakukan sistem fattening (penggemukan) domba bakalan jantan dengan waktu yang relative lebih pendek dibandingkan sistem breeding yaitu hanya 100 hari (Nuraini, 2014). Penambahan kandang sebanyak 6 flok dengan masing-masing berukuran $2 \times 3 \mathrm{~m}$ atau total luas kandang $36 \mathrm{~m}^{2}$ diharapkan mampu akan meningkatkan kapasitas kandang dari 30 ekor menjadi 80 ekor.

\section{Pelatihan dan paraktek pembuatan pakan alternatif domba}

Pelatihan pembuatan pakan alternative meliputi sajian materi dan praktek pembuatan silase dan amoniasi pakan. Silase adalah pengawetan hijaun dengan tujuan mempertahankan kualitas pakan dan menyimpan kelebihan pakan di musim hujan untuk persediaan musim kemarau sedangkan amoniasi adalah pemanfaatan jerami dan hijauan berseratkasar tinggi untuk meningkatkan nilai $\mathrm{N}$ di dalamnya.

\section{Pendampingan breeding dan fattening domba}

Manajemen pakan dan pemeliharaan yang baik akan berdampak pada produktivitas domba baik pada pertambahan bobot badan dan produktivitas anak. Karenanya dilakukan pendampingan pada peternak terkait pemberian pakan ternak yang optimal sesuai kebutuh ternak domba itu sendiri. Evaluasi breeding minimal dapat dilakukan dalam jangka waktu 1 tahun sedangkan fattening dalam jangka waktu 3 bulan (100 hari) (Nuraini, 2014).

\section{iii) Evaluasi}

Hasil dari evaluasi kegiatan pengabdian selama Oktober s/d Desember 2015 didapatkan hasil sebagaimana berikut

\section{a. Hasil kualitatif}

Hasil pelatihan budidaya jangkrik dan domba telah dilaksanakan secara intensif kepada 13 orang peserta. Dari jumlah peserta tersebut tidak ada satupun yang kesulitan dalam menerima materi dan praktek di lapangan. Hal ini dibuktikan dengan terlaksananya program sesuai dengan yang dijadwalkan.

\section{b. Hasil Kuantitatif}

Dalam hasil kuantitatif ini dilakukan evaluasi kinerja berdasar dua variable yaitu kuantitas hasil produksi dari target dan perhitungan laba bersih dalam satuan siklus usaha. Sebagaimana dapat dilihat pada table 3, data menunjukkan bahwa pada siklus usaha 1,2 dan 3 produksi jangkrik mengalami peningkatan secara bertahap. Siklus pertama hanya mendapat hasil panen $30 \mathrm{Kg}$ jangkrik dari $100 \mathrm{Kg}$ yang ditargetkan atau tercapai sebesar 30\%. Hal ini sangat wajar mengingat peserta pelatihan baru kali pertama melakukan 
usaha budidaya ini sehingga masih banyak standar prosedur belum terpenuhi, terutama jadwal pemberian pakan dan pemberian pakan tambahan yang kurang berkesinambungan. Pada siklus produksi kedua terjadi peningkatan yang cukup signifikan dimana dihasilkan $62 \mathrm{Kg}$ atau $62 \%$ dari target produksi, hal ini menunjukkan proses pendampingan dan pengalaman budidaya memberikan pengaruh yang signifikan terhadap hasil panen jangkrik. Sedangkan pada siklus ke 3 terjadi kenaikan yang kurang signifikan (3\%) dari periode sebelumnya, hal ini disebabkan karena adanya perubahan musim secara drastis pada periode pertengahan November sehingga berdampak pada perkembangan jangkrik yang terhambat.

Tabel 3. Siklus usaha dan realisasi budidaya jangkrik

\begin{tabular}{|c|c|c|r|c|c|}
\hline $\begin{array}{c}\text { Siklus } \\
\text { Usaha }\end{array}$ & $\begin{array}{c}\text { Kapasitas } \\
\text { Produksi }\end{array}$ & $\begin{array}{c}\text { Jumlah } \\
\text { Box }\end{array}$ & Target Produksi & realisasi & $\begin{array}{c}\text { \% } \\
\text { capaian }\end{array}$ \\
\hline 1 & $1 \mathrm{Kg}$ telur & 2 & $100 \mathrm{Kg}$ & $30 \mathrm{Kg}$ & 30 \\
\hline 2 & $1 \mathrm{Kg}$ telur & 1 & $100 \mathrm{Kg}$ & $62 \mathrm{Kg}$ & 62 \\
\hline 3 & $2 \mathrm{Kg}$ telur & 4 & $200 \mathrm{Kg}$ & $130 \mathrm{Kg}$ & 65 \\
\hline
\end{tabular}

Seiring berjalannya waktu maka dapat diyakini bahwa pertambahan kemampuan dan pengetahuan peternak jangkrik di bakalan krajan akan bertambah, sehingga tercapainya target produksi yaitu $50 \mathrm{Kg} /$ box (sebagaimana didapatkan peternak jangkrik senior dan profesianal) akan segera tercapai. Sebuah tantangan yang menarik adalah faktor fluktuasi harga yang sangat sulit diprediksi. Sehingga berikutnya pendampingan dan recording data produksi berdasarkan waktu tertentu perlu terus dicatat untuk dapat menerapkan strategi starting up ternak jangkrik pada waktu yang tepat agar didapat harga yang normal/tinggi ketika panen. Hal ini untuk menghindari kejadian yang tidak diinginkan yaitu rendahnya harga jangkrik di pasaran akibat over stock.

Selanjutnya dilakukan analisis ekonomi secara sederhana dari usaha yang telah dilakukan. Studi menunjukkan bahwa pendapatan bersih peternak mengalami peningkatan yang cukup berarti dari satu siklus produksi ke siklus berikutnya (lihat table 4). Periode 1 minus Rp. 250.000, paeriode 2 laba Rp. 39.000 dan periode 3 memperoleh keuntungan sebanyak Rp. 570.000.-. Jumlah ini memang tidak memenuhi target dimana dalam suasana produksi yang optimal mestinya mampu mendapatkan 1 s/d 2 Juta Rupiah dalam 1 siklus produksi menggunakan 4 box berkapasitas $3 \mathrm{Kg}$ telur jangkrik

Tabel 4 siklus usaha dan net income dalam tiap siklus produksi

\begin{tabular}{|c|c|c|l|c|}
\hline $\begin{array}{c}\text { Siklus } \\
\text { Usaha }\end{array}$ & $\begin{array}{c}\text { Kapasitas } \\
\text { Produksi }\end{array}$ & $\begin{array}{c}\text { Jumlah } \\
\text { Box }\end{array}$ & \multicolumn{1}{c|}{ Cost } & Income \\
\hline 1 & $1 \mathrm{Kg}$ telur & 2 & Rp. 970.000 & - Rp. 250.000 \\
\hline 2 & $2 \mathrm{Kg}$ telur & 2 & Rp. 1.410 .000 & Rp. 39.000 \\
\hline 3 & $2 \mathrm{Kg}$ telur & 4 & Rp. 2.430 .000 & Rp. 570.000 \\
\hline
\end{tabular}

\section{Hasil ekstensifikasi ternak domba}

Objek pengabdian yaitu Kelompok Usaha Bersama (KUBE) Domba Husnul Khotimah. Sebelum pelaksanaan program KUBE ini memiliki kandang untuk breeding atau pembibitan domba dengan kapasitas 30 ekor atau $48 \mathrm{~m}^{2}$. Dengan adanya program ini maka dilakukan perluasan kandang untuk fattening (penggemukan domba) seluas $48 \mathrm{~m}^{2}$ yang terbagi menjadi 6 flok sehingga meningkatkan daya tampung menjadi 70 ekor domba (40 ekor untuk penggemukan).

Dengan meningkatnya daya tamping kandang maka akan membuka kesempatan investor untuk menanamkan sahamnya dengan sistem bagi hasil, yaitu 45\% untuk peternak, 35\% untuk investor dan 20\% untuk pemilik tanah dalam hal ini adalah Masjid Al Mahmudi yang memiliki lahan lebih dari $3000 \mathrm{~m}^{2}$. Dengan lahan yang sedemikian luas maka akan sangat mendukung untuk ketersediaan pakan hijauan, maupun untuk lahan penggembalaan domba. Perluasan kandang terbukti efektif untuk menarik investor, terbukti dengan adanya kandang baru didapatkan investasi 30 ekor domba jantan senilai 30 juta. Dengan kalkulasi sederhana program pengabdian masyarakat ini diprediksi mampu meningkatkan produktivitas cempe dari 15 ekor/tahun menjadi 25 ekor/tahun sedangkan pendapatan dari fattening yaitu 100.000/ekor/bulan (lihat table 5). Artinya jika seorang anggota peternak memelihara 5 ekor domba jantan maka dia akan mendapatkan income Rp. 500.000/bulan

Tabel 5. Hasil Pelaksanaan Program pengabdian pada masyarakat

\begin{tabular}{|c|c|c|c|c|c|}
\hline \multirow{2}{*}{ No } & \multirow{2}{*}{ Variabel } & \multirow{2}{*}{$\begin{array}{c}\text { Sebelum } \\
\text { Pengabdian }\end{array}$} & \multicolumn{3}{|c|}{ Setelah Pengabdian } \\
\cline { 4 - 6 } & & (hanya untuk breeding) & Breeding & Fattening & Jumlah \\
\hline 1 & Luas Kandang & $48 \mathrm{~m}^{2}$ & $48 \mathrm{~m}^{2}$ & $48 \mathrm{~m}^{2}$ & $96 \mathrm{~m}^{2}$ \\
\hline
\end{tabular}




\begin{tabular}{|c|l|c|c|c|c|}
\hline 2 & $\begin{array}{l}\text { Kapasitas } \\
\text { Kandang }\end{array}$ & 30 ekor & 30 ekor & 50 ekor & 80 ekor \\
\hline 3 & Populasi Domba & 28 ekor & 28 Ekor & 30 ekor & 58 ekor \\
\hline 4 & $\begin{array}{l}\text { Potensi } \\
\text { keuntungan per } \\
\text { bulan }\end{array}$ & $\begin{array}{l}15 \text { ekor } \\
\text { cempe/tahun }\end{array}$ & $\begin{array}{c}20-25 \text { ekor } \\
\text { cempe/tahun }\end{array}$ & $100.000 /$ ekor/bulan \\
\hline
\end{tabular}

Peningkatan potensi pendapatan masyarakat diatas tidak mengherankan, mengingat dengan adanya pelatihan manajemen ternak dan formulasi pakan, peternak akan mampu untuk menghasilkan pakan yang berkualitas bagi ternak yang dipeliharanya. Pakan memiliki pengaruh sangat besar dalam industri peternakan (Yulistiani, et al. 1998), keberhasilan ternak sangat ditentukan oleh manajemen pakan (Nuraini 2014).

\section{KESIMPULAN}

Hasil kegiatan pengabdian pada masyarakat yang berlangsung selama 3 bulan dengan izin Allah telah mampu memberikan hasil yang cukup signifikan bagi masyarakat di bakalan krajan baik dari sisi ilmu maupun income. Masyarakat mendapatkan tambahan ilmu terkait budidaya jangkrik dan formulasi pakan domba sekaligus mendapatkan sarana dan prasarana secara Cuma-Cuma terutama kandang jangkrik dan domba.

Produktivitas jangkrik sebesar $62 \%$ dari target berpotensi untuk terus ditingkatkan seiring dengan bertambahnya skill dan pengalaman. Sedangkan produktivitas domba yaitu 20-25 ekor cempe/tahun untuk breeding dan Rp. 100.000,-/ekor/bulan akan dapat dicapai selama peternak dan pendamping terus berkolaborasi dalam menjalankan usaha ternak yang berkemajuan.

Rendahnya hasil panen jangkrik dari target disebabkan oleh beberapa faktor, diantaranya perubahan musim dan sumber pakan yang tidak stabil serta manajemen produksi oleh peternak yang kurang disiplin dalam pemberian makanan. Sedangkan pada ternak domba, sistem breeding dan fattening menghadapi kendala diantaranya untuk penyediaan pakan alternatif masih membutuhkan beberpaa alat yang dimiliki diantaranya mesin copper atau pencacah hijauan dan mesin pemotong bulu domba. Jika dua alat itu terpenuhi optimasi pendapatan dari sektor domba akan dapat dinaikkan secara signifikan.

\section{UCAPAN TERIMAKASIH}

Ucapan terima kasih disampaikan kepada Direktorat Jenderal Pendidikan Islam Kementerian Agama Republik Indonesia dalam Program Bantuan Peningkatan Mutu Penelitian, Publikasi Ilmiah dan Pengabdian Kepada Masyarakat tahun 2015 yang telah memberikan bimbingan teknis, evaluasi dan mendanai program ini. Masyarakat Kelurahan Bakalan Krajan Kec. Sukun Kota Malang bersama Bapak Ketua RT, RW dan Takmir Masjid Setempat. Ketua LP3M Universitas Islam Negeri Maulana Malik Ibrahim Malang dan semua pihak yang telah membantu terlaksananya program pengabdian ini. Semoga Allah mencatat kebaikan semuanya dengan balasan yang lebih baik.

\section{DAFTAR PUSTAKA}

Algifari. 2011. Hubungan antara Pendapatan per Kapita dan Indeks Pembangunan Manusia. Jurnal Ekonomi dan Bisnis, Vol. 5, No3.

Bappenas 2012. Laporan Tahunan http://simpadu-pk.bappenas.go.id/ajax datamart/download file/49

Burm, G. 2000. Budidaya Ternak Jangkrik, 1-9. Proyek Pengembangan Ekonomi Masyarakat Pedesaan, Bappenas. Kantor Deputi Menegristek Bidang Pendayagunaan dan Pemasyarakatan Ilmu Pengetahuan dan Teknologi Gedung II BPP Teknologi

Delfianizar, S dan Kasmeri, R.. 2011. Pengaruh Campuran Pakan Bravo 511 Terhadap Pertumbuhan Jangkrik (Gryllus testaceus ). Program Studi Pendidikan Biologi, Sekolah Tinggi Keguruan Dan Ilmu Pendidikan STKIP PGRI Sumatera Barat.

Ndakularak, E., N.D. Setiawina, dan I.K. Djayastra. 2012. Analisis Faktor-Faktor Yang Mempengaruhi, Fakultas Ekonomi dan Bisnis Universitas Udayana (Unud), Bali, Indonesia. 140-153.

Journal of Research on Community Engagement Vol. 1, No. 1, September 2019: 01 - 09 
Nuraini, Fitria. 2014. Ka-Do (Kambing Domba) Untuk Peternakan Indonesia. Akses online di http://himasiter.lk.ipb.ac.id/files/2014/10/KA-DO-untuk-peternakan-indonesia.pdf

Tirtamulya, K., \& Karawang, K. 2007. Optimasi Peran Ternak Domba Dalam Menunjang Usahatani Lahan Sawah, Lokakarya Nasional Sistem Pengembangan Integrasi Tani-Ternak, 17-21.Balai Pengkajian Teknologi Pertanian Jawa Barat

World Bank. 2014. Laporan Quartal Ekonomi Indonesia; Pilihan sulit. Akses online via http://www.worldbank.org/content/dam/Worldbank/document/EAP/Indonesia/IEQ-July14-BHS.pdf

Yulistiani, Tiesnamurti, B., Umi, A. dan Setiyanto, H.. 1998. Optimasi teknologi usaha ternak kambing dan domba sebagai upaya meningkatkan efisiensi usaha. Balai Penelitian Ternak, Liogor. 